\title{
The difference of musculoskeletal disorders between taxi drivers and taxi motorcyclists in Kuta District
}

\author{
L G Evayanti ${ }^{1 *}$, K S D Retayasa ${ }^{1}$, S H Indonesia ${ }^{1}$ \\ ${ }^{1}$ Faculty of Medicine and Health Sciences, Universitas Warmadewa, Denpasar, Bali \\ *luhgdeevayanti@gmail.com
}

\begin{abstract}
There are evidence of a causal relationship between physical exertion at work and work-related musculoskeletal disorders (WMSD). Taxi drivers and taxi motorcyclists generally have the risk factors of WMSD. The purpose of this study was to find out the difference of WMSD between taxi drivers and taxi motorcyclists. The design of this study was cross-sectional study. The subjects were 30 taxi drivers and 30 motorcycle taxi riders (age range 25-30 years old), who had experiences more than one year. They were selected using purposive sampling (October - December 2017). Musculoskeletal disorders obtained through interviews using Nordic Body Map questionnaire. Data were analyzed by SPSS application using independent $t$-test ( $\mathrm{p}$ value $<0.05$ ). The result of this study shown that there was difference of WMSD between taxi drivers and taxi motorcyclists significantly $(\mathrm{p}<0.05$ ). Taxi motorcyclists had more prevalence of musculoskeletal disorders than taxi drivers.
\end{abstract}

Keyword : Musculoskeletal, Taxi, Kuta District.

\section{Introduction}

Musculoskeletal disorders is a pathologic condition that involves the nerve, tendons, muscles, and supporting structures of the body. Occupational etiologic factors are major contributor to these disorders in general population. According to the study of 9,482 workers at 12 regencies in Indonesia, work related diseases include musculoskeletal disease (16\%), cardiovascular disease (8\%), nervous disorders $(6 \%)$, and respiratory problems (3\%) [2].

Indonesian online taxi industry is one of transportation sector that is growing rapidly and in great demand by consumers. Taxi motorcyclist and taxi driver are types of occupation in Indonesian online taxi industries. Transportation sectors are often associated to work-related musculoskeletal disorders (WMSD) especially in Bali where modes of transportation are diverse and convenient. Several occupational factors have been associated with WMSD such as non-ergonomic posture, repetitive motion, excessive motion, work, duration whole body vibration, and workload [3].

Occupational motorcyclists and drivers are reported widely to increase risk of low back pain. Based on previous study shown that prevalence rate of low back pain in occupational motorcyclists is higher than non-ocuppational motorcyclists [4]. The study on 200 male professional drivers aged 19-64 years in Nigeria reported that the prevalence rate of low back pain is $73,5 \%$ and then affected the driving performance of up to $74 \%$ drivers [5]. Taxi drivers and taxi motorcyclists had several risk factors of WMSD but the difference of musculoskeletal disorders was not well documented [6,7]. The aim of this study is to determine the difference of WMSD between taxi drivers and taxi motorcyclists. 


\section{Method}

The design of this study was cross-sectional study. The participants were 30 taxi drivers and 30 taxi motorcyclists (age range 25-30 years old) in Kuta District, who had experiences more than one year. They were selected using purposive sampling (October - December 2017). Musculoskeletal disorders obtained through interviews using Nordic Body Map questionnaire with Likert scale. The characteristics of participants (including age range, duration of work, and work experience range) were shown in descriptive tables. Musculoskeletal disorders were classified as mild (score < mean - standard deviation), moderate $($ score $=$ mean \pm standard deviation $)$, severe $($ score $>$ mean + standard deviation $)$. Data were analyzed by SPSS application using independent $t$-test $(\mathrm{p}$ value $<0.05)$.

\section{Results And Discussion}

The number of participants in this study is 60 people. The characteristics of participants was shown in table 1.

Table 1. The characteristics of participants in Kuta District.

\begin{tabular}{llll}
\hline \multirow{2}{*}{ Parameters } & \multicolumn{3}{c}{ Musculoskeletal Disorders } \\
\cline { 2 - 4 } Type of work & & \multicolumn{1}{c}{ Moderate } & \multicolumn{1}{c}{ Severe } \\
Taxi drivers & $7(23.3 \%)$ & $18(60 \%)$ & $5(16.7 \%)$ \\
Taxi motorcyclists & $3(10 \%)$ & $19(63.3 \%)$ & $8(27.7 \%)$ \\
Age range (years) & & & \\
$25-30$ & $5(26.3 \%)$ & $13(68.3 \%)$ & $1(5.3 \%)$ \\
$31-35$ & $0(0 \%)$ & $7(87.5 \%)$ & $1(12.5 \%)$ \\
$36-40$ & $2(18.2 \%)$ & $5(45.5 \%)$ & $4(36.4 \%)$ \\
$41-45$ & $1(9.1 \%)$ & $5(45.5 \%)$ & $5(45.5 \%)$ \\
$46-50$ & $2(18.2 \%)$ & $7(63.6 \%)$ & $2(18.2 \%)$ \\
Work experience & & & \\
(years) & & & \\
$<10$ & $6(18.8 \%)$ & $22(68.8 \%)$ & $4(12.5 \%)$ \\
$10-20$ & $2(11.1 \%)$ & $9(50 \%)$ & $7(38.9 \%)$ \\
30 & $2(20 \%)$ & $6(60 \%)$ & $2(20 \%)$ \\
Duration of work (hours) & & & \\
8 & $9(45 \%)$ & $11(55 \%)$ & $0(0 \%)$ \\
9 & $1(10 \%)$ & $9(90 \%)$ & $0(0 \%)$ \\
10 & $0(0 \%)$ & $14(73.7 \%)$ & $5(26.3 \%)$ \\
11 & $0(0 \%)$ & $0(0 \%)$ & $0(0 \%)$ \\
12 & $0(0 \%)$ & $3(27.3 \%)$ & $8(72.7 \%)$ \\
\hline
\end{tabular}

The highest score of musculoskeletal disorders using Nordic Body Map questionnaire is 57 $(44,95 \pm 5,97)$. Based on musculoskeletal disorder categories are mild 10 people $(16.7 \%)$, moderate 37 people $(61.7 \%)$ and severe 13 people $(21.7 \%)$. Based on the regions of musculoskeletal disorders, taxi drivers had pain in buttock $(83.3 \%)$, waist $(77.7 \%)$, upper neck $(73.3 \%)$, and lower neck $(70 \%)$. Futhermore, taxi motorcyclist had pain in upper neck $(93.3 \%)$, lower neck $(90 \%)$, and buttock $(80 \%)$. Based on the results of this study shown that 
there was significant difference between taxi motorcyclists and taxi drivers in Kuta District ( $\mathrm{p}$ $<0.05$ ) and shown in table 2 .

Table 2. The difference of musculoskeletal disorders between taxi drivers and taxi motorcyclists.

\begin{tabular}{lllll}
\hline \multicolumn{1}{c}{ Variabel } & N & \multicolumn{1}{c}{ Mean \pm SD } & Minimum & Maximum \\
\hline Types of Work: & & & & \\
- Taxi drivers & 30 & $43.30 \pm 6.23$ & 32 & 57 \\
- Taxi motorcyclists & 30 & $46.60 \pm 5.30^{*}$ & 37 & 57 \\
\hline
\end{tabular}

Note: $*)$ There was significant difference of musculoskeletal disorders between taxi drivers and taxi motorcyclists $(\mathrm{p}<0.05)$.

Work-related musculoskeletal disorders associated to various demographic and general features, and work-related characteristics [8]. Examples of WMSD such as sprains, strains, tears, back pain, soreness, pain, carpal tunnel syndrome and others [8]. The factors that contribute to cause driving-related musculoskeletal disorders might include seat discomfort, long time driving, prolonged sitting, poor postures, and exposure to whole body vibration. High frequency and vibration of motor induce increased muscle contraction and lactate acid accumulation. Blood circulation is not smooth due to static muscle contraction. Finally, it arises muscle pain [10]. Based on the result of this study shown that the taxi motorcyclists had score of musculoskeletal disorders higher than the taxi drivers significantly $(p<0.05)$. Chen et al (2009) also reported that the level of the whole body vibration on motorcycle larger than car, so motorcyclists is more risky to have musculoskeletal complaints [10]. According to previous study of 192 truck drivers reported that $81 \%$ respondents had musculoskeletal pain during the previous 12 months and 60\% reported low back pain [11]. Szeto et al. (2007) reported that prolonged sitting and anthropometric mismatch of urban bus drivers in Hong Kong were perceived to be most related to musculoskeletal discomfort. On physical examination, grip strength was significantly related to neck and shoulder disorders [12].

Riding a motorcycle involves complex and risky maneuvers. In addition, it is exposed to biochemical factors such as pollution, noise, and prolonged stresses from long distance driving on bumpy and damaged roads [13]. In a static sitting position, there is increased pressure in the posterior part of the spinal disc, as well as strain in the posterior passive elements of the spine [14]. Inflammation play role in the development of WMSD due to chronic repetitive contraction of muscles. Increased levels of proinflammatory cytokines such as TNF- $\alpha$, IL-6, PGE2 was found in musculotendinous injuries resulting from performing repetitive and/or forceful tasks [9]. There are three primary outcomes of acute inflammation in musculoskeletal disorder including complete resolution with restoration of normal tissue structure, healing with scar formation, and chronic fibrosis [15]. Carpal tunnel syndrome is one of work-related musculoskeletal disorders that occurs in motorcyclists due to chronic repetitive contraction of muscles [1].

\section{Conclusions}

In conclusion, work-related musculoskeletal disorders of taxi motorcyclists was found higher than taxi driver significantly. Controlling factors of work-related musculoskeletal disorders in motorcyclists and drivers is needed to reduce symptoms and clinical signs of disease. 


\section{Acknowledgement}

The authors would like to express the deepest gratitude to staffs of Faculty of Medicine and Health Science, Universitas Warmadewa for the support and contribution.

\section{References}

[1] Putz-Anderson V, Bernard B P, Burt S E, Cole L L, Fairfield-Estill C, Fine L J, Grant K A, Gjessing C, Jenkins L, Hurrell J J, Nelson N, Pfirman D, Roberts R, Stetson D, HaringSweeney M, and Tanaka S 1997 Musculoskeletal disorders and workplace factors (Columbia: National Institute for Occupational Safety and Health)

[2] Nusa Y Joseph W B S and Lampus B S 2013 Hubungan antara umur, lama kerja dan getaran dengan keluhan sistem musculoskeletal pada sopir bus trayek Manado - Lawongan di Terminal Karombasan Available from: http://fkm.unsrat.ac.id/wpcontent/uploads/2014/03/JURNAL__ YOUANI-NUSA091511016.pdf [Accessed: December 20, 2017]

[3] Hafzi M I M, Rohayu S, Faradila P N, and Wong S V 2011 Prevalence and Risk Factors of Musculoskeletal Disorders of Motorcyclists Malaysian Journal of Ergonomics 1 p 1-10

[4] Rufa'i A A, Sa'idu I A, Ahmad R Y, Elmi O S, Aliyu S U, Jajere A M, and Digil A A 2015 Prevalence and Risk Factors for Low Back Pain Among Professional Drivers in Kano, Nigeria Journal of Archives of Environmental \& Occupational Health 70(5) p 251-5

[5] da Costa B R and Vieira 2010 Risk factors for work-related musculoskeletal disorders: a systematic review of recent longitudinal studies Am J Ind Med 53 p 285-323

[6] Wibawa B M, Rahmawati Y and Rainaldo M 2018 Analisis industri bisnis jasa online ride sharing di indonesia Jurnal Bisnis dan Managemen 8(1) p 9-20

[7] Azzuhri A A, Syarafina A, Yoga F T and Amalia R 2018 A creative, innovative, and solutive transportation for Indonesia with its setbacks and how to tackle them: a case study of the phenomenal GOJEK Review of Integrative Business and Economics Research 7(1) p 59-67

[8] Bonde J P, Mikkelsen S, Andersen J H, Fallentin N, Baelum J, Svendsen S W, Thomsen J F, Frost P, and Kaergaard A 2005 Understanding work related musculoskeletal pain: does repetitive work cause stress symptoms? Occup Environ Med 62(1) p 41-48

[9] Barbe M F and Barr A E 2006 Inflammation and the pathophysiology of work-related musculoskeletal disorders Brain, Behavior, and Immunity 20 p 423-429

[10] Chen H C, Liu Y P, Chen W C, and Chen C Y 2009 Whole Body Vibration Exposure Experienced by Motorcycle Riders - An Evaluation According to ISO 2631-1 And ISO 2631-5 Standards International Journal of Industrial Ergonomics 39(5) p 708-718

[11]Robb M J M and Mansfield N J 2007 Self-reported musculoskeletal problems amongst professional truck drivers Ergonomics 50(6) p 814-827

[12] Szeto G P Y and Lam P Work-related musculoskeletal disorders in urban bus drivers of Hong Kong Journal of Occupational Rehabilitation 17(2) p 181-198

[13] Jaiyesinmi A O, Areoye O J, Olagbegi O M, Bolarinde S O and Uduonu E C 2018 Workrelated musculoskeletal disorders and predisposing factors among commercial motorcyclists in Ibadan North Local Government Area, Nigeria Occupational Health Southern Africa 24(3) p 27

[14]Callaghan J P and McGill S M 2001 Low back joint loading and kinematics during standing and unsupported sitting Ergonomics 44(3) p 280-94.

[15] Barr A E and Barbe M F 2004 Inflammation reduces physiological tissue tolerance in the development of work-related musculoskeletal disorders Journal of Electromyography and Kinesiology 14 p77-85 